\title{
Nutrient Stocks and Distribution in Ghanaian Cocoa Ecosystems
}

\author{
A. M. Mohammed $\left(\mathbb{D},{ }^{1}\right.$ J. S. Robinson $\mathbb{D}^{2}$, A. Verhoef $\mathbb{D}^{2},{ }^{2}$ and D. J. Midmore $\mathbb{D}^{2}$ \\ ${ }^{1}$ CSIR-Savanna Agricultural Research Institute, Tamale, Ghana \\ ${ }^{2}$ University of Reading, Reading, UK
}

Correspondence should be addressed to A. M. Mohammed; mamusah@yahoo.com

Received 1 April 2020; Revised 2 October 2020; Accepted 13 October 2020; Published 29 October 2020

Academic Editor: Maria Serrano

Copyright (c) 2020 A. M. Mohammed et al. This is an open access article distributed under the Creative Commons Attribution License, which permits unrestricted use, distribution, and reproduction in any medium, provided the original work is properly cited.

\begin{abstract}
There is a paucity of information on nutrient stocks and distribution in the cocoa ecosystem for the management of production sites to improve its productivity. Apart, sites with long histories of cocoa production could differ in nutrient stocks and distribution relative to recent production regions. Therefore, some existing cocoa farms in Ghana were sampled on the basis of shade management (shaded and unshaded) and production site longevity (Eastern region $>$ Western North region) to determine the nutrient stock and distributions in them. Over $93 \%$ of the total ecosystems' elementary nutrients were stored in the soil. Higher nutrient stocks occurred under shaded cocoa ecosystem. Nutrient element concentrations in cocoa tree biomasses followed the order: $\mathrm{N}>\mathrm{Ca}>\mathrm{K}>\mathrm{Mg}>\mathrm{P}>\mathrm{S}>\mathrm{Al}=\mathrm{Fe}>\mathrm{Zn}=\mathrm{Mn}$, and mostly concentrated in leaf $>$ root $=$ husk $>$ branch $>$ stem. On average, region as a main factor affected nutrient distributions. There was a sharp distinction between macronutrient and micronutrient accumulations in favour of Eastern region and Western North region, respectively. Therefore, the regional distinction with respect to macro- and micronutrients could be used as a guide to fertilizer recommendation for cocoa systems in the two regions.
\end{abstract}

\section{Introduction}

Cocoa is a cash crop grown by about 350,000 farm owners who offer employments to at least 800,000 families in Ghana. Cocoa cultivation in the past involved thinning out of natural forests before planting. Thus, cocoa trees grow well under the protection of the remnant forest tall trees providing shade. Shade management in cocoa cultivation is important to the extent that it moderates the amount of radiation incidence reaching the cocoa trees, controls temperature and air movement, and maintains fairly constant relative humidity [1]. However, cocoa is increasingly being cultivated under open full-sun conditions where, mostly, the forest is clear-felled and burnt before planting the cocoa.

Recent data on cocoa production from Cameroon, Côte d'Ivoire, Ghana, and Nigeria indicated that 8.1, 27.9, 28.1, and $3 \%$, respectively, of cocoa farms are without shade trees and that appear to suggest that cocoa cultivation also plays a role in deforestation and degradation of the natural forest [2-5]. Greenberg et al. [6] presented data on cocoa expansion in the world between 1970 and 1999, and the trend matched well with that of deforestation in cocoaproducing countries. Nonetheless, Greenberg et al. [6] and Anglaaere [7] noted that there might not be any direct causal relationship between deforestation and cocoa production since the latter most often displaces crops on rich soil or follows timber logging activities. However, other studies also noted the conversion of tropical forest to agricultural land uses as a major contributor to deforestation that threatens with extinction annually, an estimated 27,000 forest species [8-11].

Nutrient losses have been reported as a major challenge in cocoa cultivation. Several researchers found significant declines in soil organic matter and in all major nutrients under cocoa when compared with soils under forest [12-14]. Harvesting nutrient-rich biomass and exporting it lead to depletion of soil nutrients or nutritional imbalance affecting the following crop [15]. Apart, continuous cropping of cocoa affects soil conditions over time and weakens the soil's productivity due to nutrient mining. 
Nandwa and Bekunda [16] noted that sustainable agricultural production based on nutrient cycling operates only in systems where enough nutrient biomass/residue is generated and retained on-farm. Thus, information on nutrient stocks and distribution in cocoa ecosystems is vital for the management of production sites to improve productivity in cocoa systems based on the potential to recycle stored nutrients.

The aim of this study was to quantify the total nutrient stocks and distributions in Ghanaian cocoa systems, as a function of the longevity of cultivation site/region and shade management.

\section{Materials and Methods}

2.1. Physiography of the Study Area. As outlined in Mohammed et al. [17], the field studies were carried out from July to October 2011 in two regions of Ghana: the Eastern region (ER) at Duodukrom community in the Suhum district $\left(6^{\circ} 2^{\prime} \mathrm{N}, 0^{\circ} 27^{\prime} \mathrm{W}\right)$ and Western North region (WNR) at Anyinabrim in the Sefwi-Wiawso district $\left(6^{\circ} 57^{\prime} \mathrm{N}\right.$, $\left.2^{\circ} 35^{\prime} \mathrm{W}\right)$.

The Eastern region lies within the wet semiequatorial zone which is characterized by double maxima rainfall in June and October. The natural vegetation of the region consists of humid deciduous forest. Temperatures in the region are high and range between $26^{\circ} \mathrm{C}$ in August and $30^{\circ} \mathrm{C}$ in March. The relative humidity which is high throughout the year varies between 70 and $80 \%$ [17].

The Western North region lies in the equatorial climatic zone that is characterized by a double maxima rainfall occurring in May-July and September/October. Its vegetation is that of humid deciduous forest. The region is the wettest part of Ghana with an average rainfall of $1600 \mathrm{~mm}$ per annum. The climate creates much moisture culminating in high relative humidity, ranging from 70 to $90 \%$ in most parts of the region. Temperatures range between $22^{\circ} \mathrm{C}$ at nightfall and $34^{\circ} \mathrm{C}$ during the day [17].

Thus, the two regions experience similar climate and vegetation. The major soils found in both regions are mostly well-drained ochrosols or oxisols suitable for the production of industrial crops such as cocoa, pineapple, pawpaw cola nut, and oil palm. However, the Eastern region has been producing cocoa long before cultivations started in the Western North region [17].

2.2. Cocoa Farm Selections and Field Demarcations. A total of eight farms comprising four farms from each of the two regions were selected for this study based on the following criteria:

(1) The selected community in the region has at least two of both shaded and unshaded cocoa farms

(2) Of the two farms for each of the cocoa systems, one must have cocoa stands at most 15 years and the other being greater than 15 years in age as at the year 2011 (year of sampling)
(3) The owner of the selected farm must have had some training interventions on good nursery practices and planting of cocoa seedlings from Cadbury Company Ltd. through the use of the extension staff of the Cocoa Research Institute of Ghana (CRIG)

The selected four farms in the ER were shaded farms (14 and 25 years old) and unshaded farms ( 01 and 28 years old) whilst the four from the WNR were shaded (7 and 17 years old) and unshaded (13 and 27 years old) farms. At each selected farm site, a $30 \mathrm{~m} \times 90 \mathrm{~m}(0.68$ acre or $0.27 \mathrm{ha})$ plot was laid out. For analysis and biomass distribution, two $30 \mathrm{~m}$ transects that divided the plot into three of $30 \mathrm{~m} \times 30 \mathrm{~m}$ $(\sim 0.23$ acre or 0.09 ha) subplots were demarcated to represent pseudoreplications within the farm. All plant species including cocoa and noncocoa trees within the plots were marked with small pieces of masking tape and serially numbered using a pen marker [17].

The common shade trees with cocoa plantations in the study areas included Terminalia ivorensis, Terminalia superba, Entandrophragma cylindricum, Entandrophragma angolense, Newbouldia laevis, Persea americana, Celtis mildbraedii, Cola nitida, Carica papaya, Palmae sp., Spondias mombin, Ficus exasperate, Citrus sinensis (L.) Osbeck, Acacia mangium, and other forest tree species. Avocado (Persea americana) was the dominant shade tree in cocoa farms found in the Western North region whilst Newbouldia laevis was the dominant shade tree in cocoa farms found in the Eastern region. The dominant shade trees were considered as those that contributed more to the total biomass of the cocoa ecosystems and hence sampled as representative of the shade species at the studied sites in the regions [17].

2.3. Plant and Soil Sample Collection and Analysis. Total destructive sampling was performed on 3 cocoa trees per farm selected at random from the 3 subplots. The felled cocoa trees were each separated into trunks, branches, and foliage (leaves and fruits). When appropriate, the parts were cut into smaller pieces, weighed in batches, and then summed to give total component weight. For the shade trees, only the fresh leaf samples of the dominant shade trees found in each region were taken.

Approximately $100 \mathrm{~g}$ (fresh weight) each of the tree components (viz. root, stem, branch, and leaf) of cocoa and leaf samples of Persea americana and Newbouldia laevis were collected from the regions;. A quadrate of $50 \mathrm{~cm} \times 50 \mathrm{~cm}$ microplots was established in each subplots at random for floor litter and soil sampling.

Soil core samples were taken at $0-20 \mathrm{~cm}, 20-40 \mathrm{~cm}$, and 40-60 cm depths at each microplot using an auger after removing visible litter from the soil surface. Soil samples were placed in soil sampling bags and transported to the laboratory. The sampled soils were air-dried for 72 hours and lumps crushed to pass through a $2 \mathrm{~mm}$ mesh sieve to give fine earth fraction and stored for further analysis. Undisturbed soil samples were also taken for bulk density determination for each sampling depth using core samplers. All samples were transported to the Laboratory of the Soil 
Research Centre, University of Reading, UK, for further analysis.

2.3.1. Soil $\mathrm{pH}$. The $\mathrm{pH}$ of the fine earth fraction $\left(2^{\circ} \mathrm{mm}\right.$ sieved soil) was determined in a soil-to-distilled water ratio of $1: 2.5$. Ten grams $(10 \mathrm{~g})$ of the fine earth was weighed and $25 \mathrm{~mL}$ of distilled water added, stirred vigorously for 5 minutes, and allowed to stand for 30 minutes. A glass electrode $\mathrm{pH}$ meter ( $\mathrm{pH}$ meter 3310 JENWAY) was calibrated with $\mathrm{pH} 4$ and $\mathrm{pH} 7$ buffer solutions. The calibrated electrode $\mathrm{pH}$ meter was then used to read the $\mathrm{pH}$ of soils by inserting the glass electrode into the supernatant of the $1: 2.5$ soil-to-distilled water suspension.

2.3.2. Total Nitrogen Analysis. The total $\mathrm{N}$ in the leaf and soil samples was determined using the Europa Scientific ANCA System. Samples of 5-6 mg (oven-dry) leaf and 8-12 mg (air-dry) soil were weighed into small aluminium cups and pressed to seal using forceps. The sealed samples were transferred to the Europa system and arranged for purposes of distinction in a well-numbered sample holder, for analysis. The analysed data were expressed as \% N (w/ w).

2.3.3. Total P, K, Ca, $\mathrm{Mg}, \mathrm{S}, \mathrm{Mn}, \mathrm{Zn}, \mathrm{Fe}$, and Al Analysis: Nitric Acid Digestion Method. This method is based on the method described by Dr. G Merrington, Department of Soil Science, University of Reading, UK. Approximately $0.5 \mathrm{~g}$ ovendried plant samples were accurately weighed and transferred into $100 \mathrm{~mL}$ Kjeldahl digestion tubes; $10 \mathrm{~mL}$ concentrated AnalaR nitric acid was added to each tube in a fume hood. For soil samples, $1.5 \mathrm{~g}$ was weighed into the tubes and $10.5 \mathrm{~mL}$ concentrated AnalaR hydrochloric acid added to each tube followed by $3.5 \mathrm{~mL}$ concentrated AnalaR nitric acid (aqua regia digestion method). Each tube was then covered with a glass marble and left to stand overnight. The tubes were placed on a digestion block the next day and cautiously heated to $60^{\circ} \mathrm{C}$ for 3 hours followed by a gradual increase to $110^{\circ} \mathrm{C}$ and allowed to digest for 6 hours. After the samples were digested, the tubes were removed and allowed to cool and the digest was filtered through prewashed no. $540(12.5 \mathrm{~cm}$ diameter $)$ filter papers into $100 \mathrm{~mL}$ volumetric flasks. The flasks were made up to volume with ultrapure water. Aliquots of $5 \mathrm{~mL}$ from each flask were diluted by a factor of two prior to analysis by inductively coupled plasma optical emission spectrometry (ICP-OES) of $\mathrm{P}$, $\mathrm{K}, \mathrm{Ca}, \mathrm{Mg}, \mathrm{S}, \mathrm{Mn}, \mathrm{Zn}, \mathrm{Fe}$, and Al. Standards of multielement solution $(0.5,1,50$, and $100 \mathrm{mg} / \mathrm{L}$ of $\mathrm{K}, \mathrm{Ca}, \mathrm{Mg}, \mathrm{Mn}, \mathrm{Zn}, \mathrm{Fe}$, and $\mathrm{Al})$, sulphur $(50 \mathrm{mg} / \mathrm{L})$, and phosphorus $(50 \mathrm{mg} / \mathrm{L})$ as well as a blank $(0 \mathrm{mg} / \mathrm{L})$ were prepared to contain the same nitric acid concentration as in the digest to calibrate the ICP-OES. The data generated by the ICP-OES were reported in concentrations $(\mu \mathrm{g} / \mathrm{L})$ which, after correcting for the blank reading, was converted to $\mathrm{mg} / \mathrm{kg}$ dry weight based on the sample weights digested, the volume of the extract, and the dilution factor [18].

2.4. Elemental Nutrient Stocks. The soil nutrient stock was calculated using the following formula:

$$
S x=\rho \times d \times \% x,
$$

where $S x=$ soil elemental nutrient stock $(\mathrm{kg} / \mathrm{ha}), \rho=$ soil bulk density $\left(\mathrm{g} / \mathrm{cm}^{3}\right), d=$ depth $(\mathrm{cm})$ over which the sample was taken, and $\% x=$ element concentration $(\% \mathrm{w} / \mathrm{w})$.

The elemental nutrient stocks for plant components and the litter samples in each farm were estimated as the product of their mean element concentration $(\mathrm{mg} / \mathrm{kg})$ and the respective measured biomasses ( $\mathrm{kg} / \mathrm{ha}$ or $\mathrm{Mg} / \mathrm{ha}$ ).

The total cocoa ecosystem elemental nutrient stock was estimated as the sum of all the stocks of the nutrient element in the tree components, floor vegetation/litter, and soil [19].

2.5. Statistical Analyses. The data on elemental nutrient concentrations in biomass and soil samples as well as soil $\mathrm{pH}$ were subjected to descriptive statistics to obtain mean concentrations and associated standard errors using the descriptive statistics part of MINITAB v16. The normality of residuals was tested using $q-q$ plot and/or Anderson-Darling $p$ values in MINITAB v16 for all elemental nutrient stocks estimated in biomass, soils, and total ecosystem (biomass + soil stocks). Where the tested element was found to be nonnormal, the appropriate transformation was determined with the help of Box-Cox transformation and optimal or rounded lambda that gave one of the following: square root, reciprocal square root, natural logarithm, or inverse transformation method, according to the skewness of the element [20]. The transformed total ecosystems' nutrient data were analysed by the Linear MIXED Model of IBM SPSS statistics 20th edition to determine significant differences between Eastern and Western North regions and between shaded and unshaded systems as well as the interactions on nutrient stocks controlling for the ages (covariate) of cocoa farms. The means were then estimated by restricted maximum likelihood (REML) and appropriately back-transformed after separating the means using Fisher LSD pairwise comparison following significant $p$ value for $P<0.05$ to restore the original measured data form. Reduction of the measured large variables (nutrient elements) in the cocoa ecosystem was done by principal component analysis (PCA) using IBM SPSS statistics 19. Within-factor effects/patterns on the grouped nutrient elements were analysed by ANOVA and mean separation was done by LSD for $P<0.05$.

\section{Results and Discussion}

3.1. Nutrient Concentrations in Biomass Components of Cocoa Ecosystem. The elemental nutrient concentrations in biomass fractions of the cocoa tree (leaf, branch, stem, root, and husk), floor litter, and leaf samples of two dominant shade trees in farmer-managed cocoa ecosystems of Ghana were determined (Table 1$)$. The concentration $(\mathrm{mg} / \mathrm{g}$ ) ranges for the various elemental nutrients were as follows: N, 3.7-21.6; P, 0.25-2.08; K, 1.33-7.36; Ca, 5.0-29.7; Mg, 2.50-8.33; S, 0.31-1.89; $\mathrm{Mn}, 0.01-8.33 ; \mathrm{Zn}, 0.02-0.30 ; \mathrm{Fe}, 0.04-1.33$; and Al, 0.02-1.30 (Table 1). Plant nutrient analysis has been identified to be a very useful technique for the diagnosis of 
TABLE 1: Nutrient concentrations ( \pm standard error) in cocoa tree components (leaf, branch, stem, root, and husk), stumps, litter, and leaves of shade trees (Persea americana and Newbouldia laevis) in cocoa ecosystems of Ghana $(n=3)$.

\begin{tabular}{|c|c|c|c|c|c|c|c|c|c|c|}
\hline Ecosystem component & $\mathrm{N}$ & $\mathrm{P}$ & $\mathrm{K}$ & $\mathrm{Ca}$ & $\mathrm{Mg}$ & $\begin{array}{r}\mathrm{S} \\
\mathrm{mg} / \mathrm{g}\end{array}$ & $\mathrm{Mn}$ & $\mathrm{Zn}$ & $\mathrm{Fe}$ & $\mathrm{Al}$ \\
\hline \multicolumn{11}{|l|}{ Cocoa tree } \\
\hline Leaf & $18.0 \pm 0.7$ & $1.0 \pm 0.1$ & $6.6 \pm 0.9$ & $12.0 \pm 0.4$ & $5.6 \pm 0.2$ & $1.8 \pm 0.1$ & $0.23 \pm 0.01$ & $0.04 \pm 0.00$ & $0.33 \pm 0.09$ & $0.18 \pm 0.05$ \\
\hline Branch & $5.4 \pm 0.8$ & $0.3 \pm 0.0$ & $2.6 \pm 0.1$ & $6.9 \pm 0.4$ & $3.2 \pm 0.5$ & $0.3 \pm 0.0$ & $0.03 \pm 0.00$ & $0.02 \pm 0.01$ & $0.04 \pm$ & $0.02 \pm 0.00$ \\
\hline Stem & $3.7 \pm 0.6$ & $0.5 \pm 0.3$ & $4.0 \pm 0.4$ & $5.0 \pm 1.0$ & $2.5 \pm 0.3$ & $0.6 \pm 0.2$ & $0.01 \pm 0.00$ & $0.30 \pm$ & $0.12 \pm 0.05$ & $0.2=$ \\
\hline Root & $4.7 \pm 0.5$ & $1.9 \pm 0.5$ & $5.5 \pm 0.4$ & $5.0 \pm$ & $3.3 \pm 0.1$ & $0.7 \pm 0.0$ & $0.05 \pm 0.01$ & $0.06 \pm$ & $1.04\rfloor$ & $1.2=$ \\
\hline Husk & .2 & $2.1 \pm 0.0$ & $3.8 \pm$ & & $3.6 \pm 0.0$ & $1.3 \pm 0.0$ & $0.04 \pm$ & $0.05 \pm$ & $0.06=$ & $0.03 \pm$ \\
\hline \multicolumn{11}{|l|}{ Shade tree } \\
\hline P. americana & $21.6 \pm 0.3$ & $0.8 \pm 0.0$ & & & & $1.8 \pm 0.0$ & $0.14 \pm 0.00$ & $0.03 \pm 0.00$ & $0.11 \pm 0.00$ & $0.07 \pm 0.00$ \\
\hline N. laevis & $20.3 \pm 0.6$ & $1.1 \pm 0.0$ & & $16.3 \pm 0.2$ & & $1.9 \pm 0.0$ & $0.03 \pm 0.00$ & $0.03 \pm 0.00$ & $0.14 \pm 0.02$ & $0.10 \pm 0.01$ \\
\hline Stump & $3.7 \pm 0.6$ & $0.5 \pm 0.3$ & $4.0 \pm 0.4$ & $5.0 \pm 1.0$ & $2.5 \pm 0.3$ & $0.6 \pm 0.2$ & $0.01 \pm 0.00$ & $0.3 \pm 0.1$ & $0.12 \pm 0.05$ & $0.2 \pm 0.1$ \\
\hline Litter & $4.0 \pm 1.0$ & $0.7 \pm 0.0$ & $1.3 \pm 0.0$ & $29.7 \pm 0.2$ & $8.3 \pm 0.0$ & $1.6 \pm 0.0$ & $8.33 \pm 0.02$ & $0.04 \pm 0.00$ & $1.33 \pm 0.02$ & $1.30 \pm 0.02$ \\
\hline
\end{tabular}

crop nutritional disorders [21]. Thus, compared to the satisfactory nutrient ranges for fruit crops reported by Archer [21], all the parameters were within satisfactory levels for high cocoa ecosystem production. The $\mathrm{K}$ in this analysis even indicated higher concentrations than the literature satisfactory value [21].

However, on the basis of the nutrient data, the chemical characteristics of the biomass fractions of the cocoa tree were shown to vary considerably (Table 1). The cocoa leaf and husk contained on average high elemental nutrient concentrations compared with the root, stem, and branches. The highest accumulation of phosphorus $(2.08 \mathrm{mg} \cdot \mathrm{P} / \mathrm{g})$ was found in the husk and this is not surprising because phosphorus is used in seed formation and therefore extracted most from the soil during pod formation [22]. Relative to the other components of the cocoa tree, high concentrations of $\mathrm{Fe}$ and $\mathrm{Al}$ were estimated in the roots (Table 1).

Considering the measured mean concentrations of elemental nutrients for the cocoa tree, the order of nutrient accumulation in cocoa is as follows: $\mathrm{N}>\mathrm{Ca}>\mathrm{K}>\mathrm{Mg}>\mathrm{P}>\mathrm{S}>\mathrm{Al}=\mathrm{Fe}>\mathrm{Zn}=\mathrm{Mn}$.

A similar order of nutrient accumulation had been presented on Piper aduncum and Imperata cylindrica by Hartemink [23]. Anglaaere [7] noted a similar trend for leaf samples of cocoa and Gliricidia sepium.

Among the biomass fractions of cocoa, the elemental nutrient concentration on average followed the order: leaf $>$ root $=$ husk $>$ branch $>$ stem. In a similar study by Anglaaere [7] which did not include cocoa pod husk and roots, the trend established for elemental concentrations among leaf, branch, and stem of a cocoa tree agreed with the present results. Dossa et al. [24] also found nutrient concentration in a study on coffee plantation decreasing in a similar order as follows: leaf $>$ twig $>$ fine root $>$ branch $>$ stem. The high foliar elemental nutrient concentration appears to indicate a potential source of nutrient cycling in the ecosystem during leaf litter decomposition. Adu-Anning et al. [25] also observed similar high foliar nutrient concentrations in Anogeissus leiocarpus, Tectona grandis (teak), and Azadirachta indica (neem) planted for fuel in Ghana. The high concentration of $\mathrm{Ca}, \mathrm{Mg}$,
$\mathrm{Mn}, \mathrm{Al}$, and Fe nutrient elements found in the litter ( $\mathrm{Ta}$ ble 1), of which plant leaf is the major component, is an indication that high foliar nutrient concentration could form a good index for efficient nutrient cycling during litter decomposition [26].

Compared with the nutrient concentration of cocoa leaves, the leaf samples from the shade trees contained on average slightly high $\mathrm{N}, \mathrm{K}$, and $\mathrm{Ca}$ concentrations but low $\mathrm{Mn}, \mathrm{Zn}, \mathrm{Fe}$, and $\mathrm{Al}$ concentrations (Table 1). This means that pruning the shade trees could potentially contribute their accumulated nutrients to enrich soil fertility via nutrient cycling in the ecosystem. Conversely, it could also lead to loss of substantial amount of nutrients when the pruned biomass is exported/carried away as fuelwood.

\subsection{Total Nutrient Stocks in the Biomass of Cocoa Ecosystem.} tThe total elemental nutrient stock in biomass of the cocoa ecosystem is the sum of the nutrient stocks in cocoa trees, shade trees, stumps, and litter. Table 2 presents the estimated mean elemental nutrient stocks in the biomass of the cocoa ecosystem in Ghana. The estimated (mean \pm s.e) elemental nutrient stocks in the biomass of cocoa systems (kg/ha) were as follows: N, $481 \pm 45 ; \mathrm{P}, 38 \pm 3$; K, $206 \pm 19$; $\mathrm{Ca}, 555 \pm 50 ; \mathrm{Mg}, 195 \pm 12 ; \mathrm{S}, 50 \pm 5 ; \mathrm{Mn}, 7.4 \pm 0.4 ; \mathrm{Zn}$, $4.6 \pm 0.2 ; \mathrm{Fe}, 20.0 \pm 0.9$, and $\mathrm{Al}, 20.1 \pm 0.9$ (Table 2). The $\mathrm{N}$ and $\mathrm{Ca}$ were the highest nutrient elements accumulated in cocoa ecosystem biomass. Dossa et al. [24] reported similar high $\mathrm{N}$ content in vegetation biomass. Owusu-Sekyere et al. [27] attributed the large removal of $\mathrm{Ca}$ from soils into biomass as the cause of increased acidity reported in Ghanaian cocoa soils.

The elemental nutrient stocks differed with respect to region, system, and their interactions. The cocoa ecosystem biomass in the ER contained higher elemental nutrient stocks than in the WNR except in Fe stocks, where they did not differ (Table 2). Significant amounts of the elemental nutrient stocks occurred with the shaded system having high $\mathrm{N}, \mathrm{K}, \mathrm{Ca}$, and $\mathrm{S}$, but less $\mathrm{Zn}$ than the unshaded system. Biomass stocks of $\mathrm{P}, \mathrm{Mg}, \mathrm{Mn}, \mathrm{Fe}$, and $\mathrm{Al}$ appeared not to depend on the presence or absence of shade trees in the ecosystems. 
TABle 2: Nutrient stocks in the biomass components (cocoa and shade trees, stumps, and floor litter) of cocoa ecosystems $(n=3)$.

\begin{tabular}{|c|c|c|c|c|c|c|c|c|c|c|c|}
\hline Factor & Treatment & $\mathrm{N}$ & $\mathrm{P}$ & $\mathrm{K}$ & $\mathrm{Ca}$ & $\begin{array}{l}\mathrm{Mg} \\
\mathrm{kg} / \mathrm{ha}\end{array}$ & S & $\mathrm{Mn}$ & $\mathrm{Zn}$ & $\mathrm{Fe}$ & $\mathrm{Al}$ \\
\hline \multirow{2}{*}{ Region } & ER & $495.0 \mathrm{a}^{1}$ & $42.6 a$ & $217.9 \mathrm{a}$ & $591.7 \mathrm{a}$ & $214.1 \mathrm{a}$ & $51.9 \mathrm{a}$ & $7.0 \mathrm{a}$ & $5.0 \mathrm{a}$ & $21.2 \mathrm{a}$ & $21.8 \mathrm{a}$ \\
\hline & WNR & $436.7 \mathrm{~b}$ & $27.8 \mathrm{~b}$ & $154.3 \mathrm{~b}$ & $406.5 b$ & $154.3 \mathrm{~b}$ & $36.4 \mathrm{~b}$ & $6.8 \mathrm{~b}$ & $3.9 \mathrm{~b}$ & $18.7 \mathrm{a}$ & $18.3 \mathrm{~b}$ \\
\hline \multirow{2}{*}{ System } & $\mathrm{S}$ & $523.6 \mathrm{a}$ & $36.6 a$ & $202.4 \mathrm{a}$ & $549.5 a$ & $183.8 \mathrm{a}$ & $54.1 \mathrm{a}$ & $7.4 \mathrm{a}$ & $4.0 \mathrm{~b}$ & $20.6 a$ & $19.9 \mathrm{a}$ \\
\hline & $\mathrm{U}$ & $343.0 \mathrm{~b}$ & $31.2 \mathrm{a}$ & $163.1 \mathrm{~b}$ & $429.2 b$ & $174.8 \mathrm{a}$ & $35.3 \mathrm{~b}$ & $6.5 \mathrm{a}$ & $4.7 \mathrm{a}$ & $19.3 \mathrm{a}$ & $20.3 \mathrm{a}$ \\
\hline \multirow{4}{*}{ Region*system } & $\mathrm{ER} * \mathrm{~S}$ & $836.8 \mathrm{a}$ & $62.8 \mathrm{a}$ & $363.0 \mathrm{a}$ & $917.4 \mathrm{a}$ & $266.4 \mathrm{a}$ & $90.4 \mathrm{a}$ & $7.8 \mathrm{a}$ & $5.2 \mathrm{a}$ & $22.9 \mathrm{a}$ & $22.7 \mathrm{a}$ \\
\hline & $\mathrm{ER} * \mathrm{U}$ & $351.5 b$ & $32.3 \mathrm{~b}$ & $155.6 \mathrm{~b}$ & $437.3 b$ & $178.7 \mathrm{~b}$ & $36.4 \mathrm{~b}$ & $6.3 \mathrm{a}$ & $4.8 \mathrm{a}$ & $19.4 \mathrm{a}$ & $20.9 \mathrm{a}$ \\
\hline & $\mathrm{WNR} * \mathrm{~S}$ & $381.2 \mathrm{~b}$ & $25.9 b$ & $140.3 \mathrm{~b}$ & $392.2 b$ & $140.5 \mathrm{c}$ & $38.7 \mathrm{~b}$ & $7.0 \mathrm{a}$ & $3.3 \mathrm{~b}$ & $18.2 \mathrm{a}$ & $17.1 \mathrm{a}$ \\
\hline & $\mathrm{WNR} * \mathrm{U}$ & $337.3 b$ & $30.2 \mathrm{~b}$ & $171.5 \mathrm{~b}$ & $420.5 b$ & $171.2 \mathrm{~b}$ & $34.4 \mathrm{~b}$ & $6.7 \mathrm{a}$ & $4.6 \mathrm{a}$ & $19.2 \mathrm{a}$ & $19.6 \mathrm{a}$ \\
\hline \multicolumn{2}{|c|}{ Coefficient of variation (\%) } & 25.6 & 22.8 & 24.8 & 16.9 & 16.0 & 22.8 & 16.3 & 16.8 & 16.5 & 13.4 \\
\hline
\end{tabular}

${ }^{1}$ Different letters within the same factor and column indicate significant difference at $P<0.05$ using the LSD method. ER = Eastern region, WNR $=$ Western North region, $\mathrm{S}=$ shaded cocoa, and $\mathrm{U}=$ unshaded cocoa.

TABLE 3: Soil chemical properties ( \pm standard error) at different depths under cocoa ecosystems in the Eastern and Western North regions of Ghana.

\begin{tabular}{lccccccccccc}
\hline Soil depth & $\begin{array}{c}\mathrm{pH} \\
(1: 2.5)\end{array}$ & $\mathrm{N}$ & $\mathrm{P}$ & $\mathrm{K}$ & $\mathrm{Ca}$ & $\mathrm{Mg}$ & $\mathrm{S}$ & $\mathrm{Mn}$ & $\mathrm{Zn}$ & $\mathrm{Fe}$ & $\mathrm{Al}$ \\
\multicolumn{2}{l}{} & & & & & & & & \\
\hline \multicolumn{2}{l}{ Eastern region } & & & & & & & & & \\
\hline $0-20 \mathrm{~cm}$ & $6.7 \pm 0.1$ & $1.6 \pm 0.2$ & $0.3 \pm 0.0$ & $1.3 \pm 0.3$ & $2.7 \pm 0.2$ & $2.0 \pm 0.2$ & $0.2 \pm 0.0$ & $0.72 \pm 0.07$ & $0.06 \pm 0.03$ & $19 \pm 2$ & $20 \pm 3$ \\
\hline $20-40 \mathrm{~cm}$ & $6.1 \pm 0.1$ & $0.8 \pm 0.1$ & $0.3 \pm 0.0$ & $1.8 \pm 0.3$ & $1.9 \pm 0.3$ & $2.2 \pm 0.2$ & $0.1 \pm 0.0$ & $0.69 \pm 0.06$ & $0.07 \pm 0.01$ & $22 \pm 2$ & $24 \pm 4$ \\
\hline $40-60 \mathrm{~cm}$ & $5.7 \pm 0.1$ & $0.6 \pm 0.1$ & $0.2 \pm 0.0$ & $1.5 \pm 0.3$ & $1.9 \pm 0.2$ & $2.3 \pm 0.3$ & $0.1 \pm 0.0$ & $0.61 \pm 0.03$ & $0.08 \pm 0.01$ & $23 \pm 2$ & $26 \pm 4$ \\
\hline Western North region & & & & & & & & & & & \\
\hline $0-20 \mathrm{~cm}$ & $5.5 \pm 0.3$ & $2.5 \pm 0.3$ & $0.2 \pm 0.0$ & $0.2 \pm 0.0$ & $1.6 \pm 0.4$ & $0.5 \pm 0.1$ & $0.2 \pm 0.0$ & $0.31 \pm 0.08$ & $0.02 \pm 0.00$ & $27 \pm 6$ & $28 \pm 3$ \\
\hline $20-40 \mathrm{~cm}$ & $4.7 \pm 0.3$ & $1.2 \pm 0.2$ & $0.2 \pm 0.0$ & $0.2 \pm 0.0$ & $1.0 \pm 0.3$ & $0.5 \pm 0.1$ & $0.2 \pm 0.1$ & $0.23 \pm 0.06$ & $0.08 \pm 0.01$ & $39 \pm 10$ & $34 \pm 4$ \\
\hline $40-60 \mathrm{~cm}$ & $4.6 \pm 0.2$ & $0.8 \pm 0.1$ & $0.2 \pm 0.0$ & $0.3 \pm 0.0$ & $0.6 \pm 0.1$ & $0.5 \pm 0.0$ & $0.2 \pm 0.1$ & $0.17 \pm 0.02$ & $0.17 \pm 0.03$ & $49 \pm 10$ & $50 \pm 4$ \\
\hline
\end{tabular}

Based on regions, however, a significant variation $(P<0.05)$ on the production of elemental nutrient stocks, particularly the major elements, occurred under shaded systems. For the system without shade, elemental nutrient stocks were the same in the ER and WNR.

3.3. Soil Chemical Properties in the Cocoa Ecosystems. Several properties are important in determining soil fertility. One property is the adsorption and storage of nutrients on the surfaces of soil particles. Such adsorption of a number of nutrients is caused by an attraction of positively charged nutrient elements (cations) to negatively charged soil particles. Soil surfaces are noted to possess negative charges, especially where clay minerals and organic matter (humus) are present [28]. Negative charges of organic matter arise largely from carboxylic $(-\mathrm{COOH})$ and phenolic $(-\mathrm{O}-\mathrm{H})$ acid functional groups. Since these functional groups are weak acids, the negative charge from organic matter increases as the soil solution $\mathrm{pH}$ increases. This property allows also adsorbed cations on the soil surface to be exchanged with other cations in soil solution.

Table 3 presents some chemical properties of the soils under cocoa ecosystems at the studied sites in the Eastern (ER) and Western North regions (WNR) of Ghana. The soil $\mathrm{pH}$ range of 5.7 to 6.7 in the ER is moderately to slightly acidic. The soil $\mathrm{pH}$ range agreed with the average $\mathrm{pH}$ value of 6.5 [29] and is within the range of 5.6-7.2 [30] reported as being the ideal condition for plant nutrient availability in mineral soils. Ofori-Frimpong et al. [31] also found the average $\mathrm{pH}$ of 6.4 in $0-15 \mathrm{~cm}$ depth of soils under cocoa systems in the ER. Owusu-Bennoah et al. [32] reported the average $\mathrm{pH}$ value of 5.9 in surface soils under cocoa systems and attributed it to the accumulation of released bases from decomposing litter.

The soils in WNR in contrast were acidic with the $\mathrm{pH}$ values ranging from $4.6 \pm 0.2$ to $5.5 \pm 0.3$ (Table 3 ). The acidity increased with increasing soil depth. Highly acid soils limit plant root developments that in turn limit the plant ability to capture nutrients at depth to meet its nutrient requirements. This problem of acid soils often leads to soil infertility and land abandonment to clear new forest land for agriculture, an act that plays a major role in deforestation [33]. The highest average $\mathrm{pH}$ value of 5.5 is even less than the critical $\mathrm{pH}$ value of 6.5 reported by Foth and Ellis [29] and below the range of 5.6 to 7.2 reported by Ahenkorah et al. [30] as suitable soil $\mathrm{pH}$ conditions for plant growth. Egbuchua and Bosah [38] however noted that tree species will grow best in soils with $\mathrm{pH}$ range between 4.5 and 6.5. This means that the soil $\mathrm{pH}$ values measured in both the ER and WNR were conducive for cocoa cultivation. The soils of the ER were slightly acidic and generally richer in $\mathrm{P}, \mathrm{K}, \mathrm{Ca}$, $\mathrm{Mg}$, and $\mathrm{Mn}$ concentrations at all depths within $60 \mathrm{~cm}$ when compared to the soils from WNR. The general pattern of elemental nutrient concentration in the soils of ER was as follows: $\mathrm{Al}=\mathrm{Fe}>\mathrm{Ca}=\mathrm{Mg}>\mathrm{K}>\mathrm{N}>\mathrm{Mn}>\mathrm{P}>\mathrm{S}>\mathrm{Zn}$. The 
TABle 4: Soil (0 - $60 \mathrm{~cm}$ depths) nutrient stocks in cocoa ecosystems $(n=3)$.

\begin{tabular}{lccccccccccc}
\hline \multirow{2}{*}{ Factor } & \multirow{2}{*}{ Treatment } & $\mathrm{N}$ & $\mathrm{P}$ & $\mathrm{K}$ & $\mathrm{Ca}$ & $\mathrm{Mg}$ & $\mathrm{S}$ & $\mathrm{Mn}$ & $\mathrm{Zn}$ & $\mathrm{Fe}$ & $\mathrm{Al}$ \\
& & & & & \multicolumn{2}{c}{$\mathrm{Mg} / \mathrm{ha}$} & & \\
\multirow{2}{*}{ Region } & $\mathrm{ER}$ & $8.5 \mathrm{~b}$ & $2.4 \mathrm{a}$ & $12.5 \mathrm{a}$ & $19.6 \mathrm{a}$ & $20.3 \mathrm{a}$ & $1.1 \mathrm{a}$ & $6.2 \mathrm{a}$ & $0.6 \mathrm{~b}$ & $190.1 \mathrm{~b}$ & $198.0 \mathrm{~b}$ \\
& $\mathrm{WNR}$ & $12.0 \mathrm{a}$ & $1.9 \mathrm{~b}$ & $2.1 \mathrm{~b}$ & $8.7 \mathrm{~b}$ & $4.4 \mathrm{~b}$ & $1.1 \mathrm{a}$ & $2.0 \mathrm{a}$ & $0.8 \mathrm{a}$ & $287.7 \mathrm{a}$ & $331.2 \mathrm{a}$ \\
\hline \multirow{2}{*}{ System } & $\mathrm{S}$ & $10.2 \mathrm{a}$ & $1.7 \mathrm{~b}$ & $6.1 \mathrm{a}$ & $12.5 \mathrm{~b}$ & $13.7 \mathrm{a}$ & $1.1 \mathrm{a}$ & $4.5 \mathrm{a}$ & $0.7 \mathrm{a}$ & $216.4 \mathrm{~b}$ & $299.9 \mathrm{a}$ \\
& $\mathrm{U}$ & $10.3 \mathrm{a}$ & $2.5 \mathrm{a}$ & $4.2 \mathrm{~b}$ & $15.8 \mathrm{a}$ & $11.0 \mathrm{~b}$ & $1.1 \mathrm{a}$ & $3.7 \mathrm{~b}$ & $0.6 \mathrm{a}$ & $252.7 \mathrm{a}$ & $219.4 \mathrm{~b}$ \\
\hline \multirow{3}{*}{ Region* system } & $\mathrm{ER} * \mathrm{~S}$ & $10.6 \mathrm{~b}$ & $2.3 \mathrm{a}$ & $20.8 \mathrm{a}$ & $19.0 \mathrm{a}$ & $24.0 \mathrm{a}$ & $1.1 \mathrm{~b}$ & $7.4 \mathrm{a}$ & $0.8 \mathrm{a}$ & $256.2 \mathrm{~b}$ & $296.0 \mathrm{~b}$ \\
& $\mathrm{ER} * \mathrm{U}$ & $6.5 \mathrm{c}$ & $2.4 \mathrm{a}$ & $7.5 \mathrm{~b}$ & $20.3 \mathrm{a}$ & $16.5 \mathrm{~b}$ & $1.0 \mathrm{~b}$ & $5.0 \mathrm{~b}$ & $0.5 \mathrm{~b}$ & $141.1 \mathrm{~d}$ & $133.3 \mathrm{c}$ \\
& $\mathrm{WNR} * \mathrm{~S}$ & $9.8 \mathrm{~b}$ & $1.2 \mathrm{~b}$ & $1.8 \mathrm{~d}$ & $6.1 \mathrm{a}$ & $3.4 \mathrm{~d}$ & $1.1 \mathrm{~b}$ & $1.5 \mathrm{~d}$ & $0.7 \mathrm{a}$ & $182.7 \mathrm{c}$ & $303.8 \mathrm{~b}$ \\
& $\mathrm{WNR} * \mathrm{U}$ & $14.2 \mathrm{a}$ & $2.7 \mathrm{a}$ & $2.4 \mathrm{c}$ & $11.3 \mathrm{a}$ & $5.4 \mathrm{c}$ & $1.2 \mathrm{a}$ & $2.4 \mathrm{c}$ & $0.9 \mathrm{a}$ & $452.8 \mathrm{a}$ & $361.1 \mathrm{a}$ \\
\hline \multirow{2}{*}{ Coefficient of variation $(\%)$} & 8.1 & 14.4 & 5.6 & 16.1 & 7.0 & 7.8 & 9.6 & 17.3 & 1.3 & 1.6 \\
\hline
\end{tabular}

${ }^{1}$ Different letters within the same factor and column indicate significant difference at $P<0.05$ using the LSD method. ER = Eastern region, WNR $=$ Western North region, $\mathrm{S}=$ shaded cocoa, and $\mathrm{U}=$ unshaded cocoa.

WNR soils contained higher concentrations of $\mathrm{N}, \mathrm{S}, \mathrm{Zn}, \mathrm{Fe}$, and $\mathrm{Al}$ from the topsoil down to $60 \mathrm{~cm}$ depth than those determined in the ER soils (Table 3). The elemental nutrient concentrations in the WNR soils followed the order: $\mathrm{Al}=\mathrm{Fe}>\mathrm{N}>\mathrm{Ca}>\mathrm{Mg}>\mathrm{P}=\mathrm{K}=\mathrm{S}=\mathrm{Mn}>\mathrm{Zn}$.

Thus, nutrient pattern variability also existed between the soils of the two regions as the soils from WNR contained higher $\mathrm{N}$ than those from ER. Nitrogen is an important nutrient element required for plant development and growth [35]. Of all the elemental nutrients, it is $\mathrm{Al}$ that increased substantially in both soils with soil depth, and this was more pronounced in the WNR soils where $\mathrm{Al}$ concentration from the topsoil increased by $21.4 \%$ and $78.6 \%$ in $20-40$ and $40-60 \mathrm{~cm}$ depths, respectively. Although the $\mathrm{Al}$ concentrations in the soils of the two regions were high, their saturations were lower than $60 \%$, suggesting the absence of $\mathrm{Al}$ toxicity in the soils [36]. However, the soils in the WNR had more than $10 \% \mathrm{Al}$ saturation and so presented a potential acidity problem corroborating the measured $\mathrm{pH}$ ranged from $4.6 \pm 0.2$ to $5.5 \pm 0.3$ (Table 3).

3.4. Total Nutrient Stock in Soils under Cocoa Ecosystem. Differences in elemental nutrient stocks in the $0-60 \mathrm{~cm}$ depth of soils under the cocoa ecosystem are shown in Table 4. The mean stock of nutrient elements $(\mathrm{Mg} / \mathrm{ha})$ in the soils of the cocoa ecosystems was as follows: $\mathrm{N}, 10.3 \pm 0.5$; P, $2.1 \pm 0.1 ; \mathrm{K}, 7 \pm 1 ; \mathrm{Ca}, 14 \pm 1 ; \mathrm{Mg}, 12 \pm 1 ; \mathrm{S}, 1.10 \pm 0.01 ; \mathrm{Mn}$, $4.1 \pm 0.4 ; \mathrm{Zn}, 0.72 \pm 0.04 ; \mathrm{Fe}, 253 \pm 22 ;$ and $\mathrm{Al}, 270 \pm 17$ (Table 4). These ranges revealed that the soils were rich in $\mathrm{Al}$ and Fe which usually are associated with highly weathered soils [36].

Table 4 also shows that the soils from the two regions differed in the elemental nutrient content between plant macronutrients ( $\mathrm{N}, \mathrm{P}, \mathrm{K}, \mathrm{Ca}, \mathrm{Mg}$, and $\mathrm{S}$ ) and micronutrients $(\mathrm{Mn}, \mathrm{Zn}$, and $\mathrm{Fe}$ ) including $\mathrm{Al}$. The soils from $\mathrm{ER}$ were richer in macronutrients, particularly $\mathrm{P}, \mathrm{K}, \mathrm{Ca}$, and $\mathrm{Mg}$, but poorer in the micronutrients and $\mathrm{Al}$, compared with the soils from the WNR. The low P status of the soils from WNR could be attributed to the high acidic nature of the soils $(\mathrm{pH}=4.6-5.5$, Table 3 ) that has the potential of causing $\mathrm{P}$ chelation. Phosphorus forms complex compounds with $\mathrm{Al}$ and $\mathrm{Fe}$ in soils with low $\mathrm{pH}$. Consequently, the mobility of $\mathrm{P}$ in $\mathrm{Fe}$ - and Al-rich soils is constrained [35].

Significant effects of the management system of the cocoa ecosystem on soil nutrient stocks occurred (Table 4). However, unlike the trend observed due to regional influence, there was no major difference in response between macro- and micronutrient elements. The lack of a clear trend for the differences in soil elemental nutrients under the cocoa ecosystem with or without shade trees suggests minimal to no competition between the cocoa and shade trees. Conversely, the topsoil did not benefit from additional nutrient inputs from the shade trees.

3.5. Total Elemental Nutrient Stocks in the Cocoa Ecosystem. The total elemental nutrient stocks were estimated as the sum of the nutrient stocks in biomass and the nutrient stocks in the $0-60 \mathrm{~cm}$ depth of soil under the cocoa ecosystem according to region and systems. Table 5 presents the estimated total elemental nutrient stocks of the cocoa ecosystem of Ghana. The nutrient ranges and average stocks for the various elements were as follows: N: 6.69-17.64 with mean $\mathrm{N}$ stock of $10.9 \pm 0.5 \mathrm{Mg} / \mathrm{ha}, \mathrm{P}: 1.07-3.39$ with mean $\mathrm{P}$ stock of $2.2 \pm 0.1 \mathrm{Mg} / \mathrm{ha}, \mathrm{K}: 1.89-26.05$ with mean $\mathrm{K}$ stock of $7 \pm 1 \mathrm{Mg} / \mathrm{ha}$, Ca: 4.46-21.27 with mean $\mathrm{Ca}$ stock of $15 \pm 1 \mathrm{Mg} / \mathrm{ha}, \mathrm{Mg}$ : $3.43-29.36$ with mean $\mathrm{Mg}$ stock of $13 \pm 1 \mathrm{Mg} / \mathrm{ha}$, S: $0.98-2.61$ with mean $\mathrm{S}$ stock of $1.63 \pm 0.08 \mathrm{Mg} / \mathrm{ha}, \mathrm{Mn}: 0.97-8.01$ with mean Mn stock of $4.1 \pm 0.4 \mathrm{Mg} / \mathrm{ha}, \mathrm{Zn}: 0.43-1.49$ with mean $\mathrm{Zn}$ stock of $0.72 \pm 0.04 \mathrm{Mg} / \mathrm{ha}$, Fe: $98.0-635.9$ with mean Fe stock of $253 \pm 22 \mathrm{Mg} / \mathrm{ha}$, and Al: 123.4-403.4 with mean $\mathrm{Al}$ stock being $270 \pm 17 \mathrm{Mg} / \mathrm{ha}$ (Table 5).

Based on the average elemental nutrient stocks in soil and biomass of the cocoa ecosystem, the contribution of the soil nutrient stock from $0-60 \mathrm{~cm}$ depth to the total ecosystem was as follows: N: $93.98 \%$, P: $98.57 \%$, K: $96.24 \%$, Ca: 95.55\%, Mg: 98.17\%, S: 67.23\%, Mn: 99.35\%, Zn: 99.35\%, Fe: $99.92 \%$, and $\mathrm{Al}: 99.93 \%$. On average, over $93 \%$ of all the elemental nutrient stocks but $S(\sim 67 \%)$ in the cocoa ecosystem were stored in the $0-60 \mathrm{~cm}$ depth of the soil. It is, therefore, not surprising that the trends of various elemental nutrient stock variations in the cocoa ecosystem as influenced by the factors, regions, shade systems, and their 
TABLe 5: Total nutrient stocks in cocoa ecosystems (biomass + soil at $0-60 \mathrm{~cm}$ depth) $(n=3)$.

\begin{tabular}{|c|c|c|c|c|c|c|c|c|c|c|c|}
\hline Factor & Treatment & $\mathrm{N}$ & $\mathrm{P}$ & $\mathrm{K}$ & $\mathrm{Ca}$ & $\mathrm{Mg}$ & $\mathrm{S}$ & $\mathrm{Mn}$ & $\mathrm{Zn}$ & $\mathrm{Fe}$ & $\mathrm{Al}$ \\
\hline \multirow{2}{*}{ Region } & ER & $9.2 b^{1}$ & $2.4 \mathrm{a}$ & $12.8 \mathrm{a}$ & $20.4 \mathrm{a}$ & $20.5 a$ & $1.4 \mathrm{~b}$ & $6.2 \mathrm{a}$ & $0.6 \mathrm{~b}$ & $190.3 b$ & $198.8 \mathrm{~b}$ \\
\hline & WNR & $12.6 \mathrm{a}$ & $2.0 \mathrm{~b}$ & $2.3 \mathrm{~b}$ & $9.3 \mathrm{~b}$ & $4.6 \mathrm{~b}$ & $1.9 \mathrm{a}$ & $2.0 \mathrm{~b}$ & $0.8 \mathrm{a}$ & $287.9 \mathrm{a}$ & $331.5 \mathrm{a}$ \\
\hline \multirow{2}{*}{ System } & $\mathrm{S}$ & $11.1 \mathrm{a}$ & $1.8 \mathrm{~b}$ & $6.6 a$ & $13.4 \mathrm{~b}$ & $14.0 \mathrm{a}$ & $1.4 \mathrm{~b}$ & $4.5 \mathrm{a}$ & $0.7 \mathrm{a}$ & $216.8 \mathrm{~b}$ & $300.0 \mathrm{a}$ \\
\hline & $\mathrm{U}$ & $10.7 \mathrm{a}$ & $2.6 \mathrm{a}$ & $4.5 \mathrm{~b}$ & $16.2 \mathrm{a}$ & $11.1 \mathrm{~b}$ & $1.9 \mathrm{a}$ & $3.8 \mathrm{~b}$ & $0.6 \mathrm{a}$ & $252.8 \mathrm{a}$ & $219.8 \mathrm{~b}$ \\
\hline \multirow{4}{*}{ Region $*$ system } & $\mathrm{ER} * \mathrm{~S}$ & $11.5 b$ & $2.4 \mathrm{a}$ & $21.2 \mathrm{a}$ & $20.1 \mathrm{a}$ & $24.3 \mathrm{a}$ & $1.4 \mathrm{~b}$ & $7.4 \mathrm{a}$ & $0.8 \mathrm{a}$ & $256.6 b$ & $295.9 b$ \\
\hline & $\mathrm{ER} * \mathrm{U}$ & $6.9 c$ & $2.5 \mathrm{a}$ & $7.7 \mathrm{~b}$ & $20.8 \mathrm{a}$ & $16.7 \mathrm{~b}$ & $1.3 \mathrm{~b}$ & $5.1 \mathrm{~b}$ & $0.5 b$ & $141.2 \mathrm{~d}$ & $133.6 c$ \\
\hline & $\mathrm{WNR} * \mathrm{~S}$ & $10.7 \mathrm{~b}$ & $1.2 \mathrm{~b}$ & $2.0 \mathrm{~d}$ & $6.7 \mathrm{a}$ & $3.6 \mathrm{~d}$ & $1.4 \mathrm{~b}$ & $1.6 \mathrm{~d}$ & $0.7 \mathrm{a}$ & $183.1 \mathrm{c}$ & $304.1 \mathrm{~b}$ \\
\hline & $\mathrm{WNR} * \mathrm{U}$ & $14.5 \mathrm{a}$ & $2.7 \mathrm{a}$ & $2.6 \mathrm{c}$ & $11.7 \mathrm{a}$ & $5.6 \mathrm{c}$ & $2.5 \mathrm{a}$ & $2.5 \mathrm{c}$ & $0.9 \mathrm{a}$ & $452.6 \mathrm{a}$ & $361.4 \mathrm{a}$ \\
\hline \multicolumn{2}{|c|}{ Coefficient of variation (\%) } & 7.7 & 13.8 & 5.6 & 15.0 & 6.7 & 18.9 & 9.6 & 17.1 & 1.3 & 1.6 \\
\hline
\end{tabular}

${ }^{1}$ Different letters within the same factor and column indicate significant difference at $P<0.05$ using the LSD method. ER = Eastern region, WNR $=$ Western North region, $\mathrm{S}=$ shaded cocoa, and $\mathrm{U}=$ unshaded cocoa.

TABLE 6: Rotated component matrix.

\begin{tabular}{lcccccccccc}
\hline Comp & $\mathrm{Fe}$ & $\mathrm{N}$ & $\mathrm{Zn}$ & $\mathrm{S}$ & $\mathrm{Al}$ & $\mathrm{Mn}$ & $\mathrm{Ca}$ & $\mathrm{Mg}$ & $\mathrm{K}$ & $\mathrm{P}$ \\
\hline 1 & 0.969 & 0.949 & 0.896 & 0.834 & 0.814 & -0.052 & -0.089 & -0.262 & -0.133 & 0.553 \\
2 & -0.056 & -0.089 & 0.049 & -0.137 & -0.284 & 0.958 & 0.924 & 0.918 & 0.855 & 0.643 \\
\hline
\end{tabular}

interactions, were similar to the effects of the soils ( Tables 4 and 5). This could be an indication of the dominance of the soil resources in the ecosystem rather than the capacity of biomass to accumulate nutrients [38].

So varied were the effects of region and shade management on the nutrient stocks due to a large number of elements (ten elements) measured that it became difficult to establish clear trends of the factor effects. Reducing the large data to two underlying linear components with the help of principal component analysis revealed the first component correlated highly with $\mathrm{Fe}, \mathrm{N}, \mathrm{Zn}, \mathrm{S}$, and $\mathrm{Al}$ (micronutrients), and the second component was strongly associated with $\mathrm{Mn}$, $\mathrm{Ca}, \mathrm{Mg}, \mathrm{P}$, and $\mathrm{K}$ (macronutrients) (Table 6). Based on the component scores with respect to region and shade management, the first component (micronutrients) had a significantly $(P<0.05)$ higher score of the correlated elemental nutrient stock in the Western North region than in the Eastern region. An indication that the WNR cocoa ecosystem is richer in Fe, N, Zn, S, and $\mathrm{Al}$ nutrient stocks than the ER. There was no significant difference with respect to the separated components between shaded and unshaded cocoa systems. Therefore, the regional distinction with respect to macro- and micronutrients could be used as a guide to fertilizer recommendation for cocoa systems in the two regions.

\section{Conclusions}

This study provided estimates of nutrient element concentrations, stocks, and distribution in Ghanaian cocoa ecosystems. The soil contained over $93 \%$ of almost all of the elemental nutrient stocks in the cocoa ecosystem, suggesting the dominating role it plays in total nutrient stocks of cocoa ecosystems. Mean concentrations of elemental nutrient accumulations for cocoa tree followed the order: $\mathrm{N}>\mathrm{Ca}>\mathrm{K}>\mathrm{Mg}>\mathrm{P}>\mathrm{S}>\mathrm{Al}=\mathrm{Fe}>\mathrm{Zn}=\mathrm{Mn}$, and their distributions followed the order: leaf $>$ root $=$ husk $>$ branch $>$ stem. High nutrient concentration in leaves of shade trees suggests that pruning the shade tree leaves could potentially add some of its highly accumulated nutrients to enhance nutrient cycling in the ecosystem

\section{Data Availability}

The data used to support the findings of this study are available from the corresponding author upon request.

\section{Conflicts of Interest}

The authors declare that there are no conflicts of interest regarding the publication of this paper.

\section{Acknowledgments}

The authors are grateful to the Ghana Education Trust Fund for the provision of funds without which the study would not have been possible. The acceptance by cocoa farmers in Ghana to use their farms for the data collection is duly acknowledged.

\section{References}

[1] G. L. Smiley and J. Kroschel, "Temporal change in carbon stocks of cocoa-gliricidia agroforests in Central Sulawesi, Indonesia," Agroforestry Systems, vol. 73, no. 3, pp. 219-231, 2008.

[2] World Bank, Ghana: Forestry Sector Review, World Bank, Washington, DC, USA, 1987.

[3] K. Cleave, "Deforestation in the western and central African rainforest: the agricultural and demographic causes, and some solutions," in Potential of natural and improved fallow using indigenous trees to facilitate cacao replanting in Ghana 76, G. J. Anim-Kwapong and K. Osei-Bonsu, Eds., pp. 533-542, Virginia Tech, Blacksburg, Virginia, 1992. 
[4] Ministry of Environment and Science, National Biodiversity Strategy for Ghana, Ministry of Environment and Science, Accra, Ghana, 2002.

[5] J. Gockowski and D. Sonwa, "Cocoa intensification scenarios and their predicted impact on $\mathrm{CO}_{2}$ emissions, biodiversity conservation, and rural livelihoods in the Guinea rain forest of west Africa," Environmental Management, vol. 48, no. 2, pp. 307-321, 2011.

[6] R. Greenberg, P. Bichier, and A. C. Angón, "The conservation value for birds of cacao plantations with diverse planted shade in Tabasco, Mexico," Animal Conservation, vol. 3, no. 2, pp. 105-112, 2000.

[7] L. C. N. Anglaaere, "Improving the sustainability of cocoa farms in Ghana through utilization of native forest trees in agroforestry systems," $\mathrm{Ph}$. D. thesis, p. 340, University of Wales, Bangor, UKUniversity of Wales, 2005.

[8] FAO, World Soil Resources: An Explanatory Note on the FAO World Soil Resources Map at 1:25 000000 Scale, Food and Agriculture Organization, Rome, Italy, 1991.

[9] R. A. Houghton, "Tropical deforestation and atmospheric carbon dioxide," Tropical Forests and Climate, vol. 19, no. 1-2, pp. 99-118, 1991

[10] N. Myers, "Tropical forests: present status and future outlook," Tropical Forests and Climate, vol. 19, no. 1-2, pp. 3-32, 1991.

[11] H. J. Geist and E. F. Lambin, "What drives tropical deforestation," LUCC Report Series 4, LUCC International Project Office, Louvain-la-Neuve, Belgium, 2001.

[12] J. O. Adejuwon and O. Ekanade, "Edaphic component of the environmental degradation resulting from the replacement of tropical rain forest by field and tree crops in sw Nigeria," International Tree Crops Journal, vol. 4, no. 4, pp. 269-282, 1987.

[13] J. Beer, A. Bonnemann, W. Chavez, H. W. Fassbender, A. C. Imbach, and I. Martel, "Modelling agroforestry systems of cacao (Theobroma cacao) with laurel (Cordia alliodora) or poro (Erythrina poeppigiana) in Costa Rica," Agroforestry Systems, vol. 12, no. 3, pp. 229-249, 1990.

[14] O. Ekanade, F. A. Adesina, and N. E. Egbe, "Sustaining tree crop production under intensive land use: an investigation into soil quality differentiation under varying cropping patterns in western Nigeria," Journal of Environmental Management, vol. 32, no. 2, pp. 105-113, 1991.

[15] A. Spangenberg, U. Grimm, J. R. Sepeda da Silva, and H. Fölster, "Nutrient store and export rates of Eucalyptus urograndis plantations in eastern Amazonia (Jari)," Forest Ecology and Management, vol. 80, no. 1-3, pp. 225-234, 1996.

[16] S. M. Nandwa and M. A. Bekunda, "Research on nutrient flows and balances in East and Southern Africa: state-of-the-art1," Agriculture, Ecosystems \& Environment, vol. 71, no. 1-3, pp. 5-18, 1998.

[17] A. M. Mohammed, J. Robinson, D. Midmore, and A. Verhoef, "Carbon storage in Ghanaian cocoa ecosystems," Carbon Management and Balance, vol. 11, no. 6, pp. 1-8, 2016.

[18] B. A. Zarcinas, B. Cartwright, and L. R. Spouncer, "Nitric acid digestion and multi-element analysis of plant material by inductively coupled plasma spectrometry," Communications in Soil Science and Plant Analysis, vol. 18, no. 1, pp. 131-146, 1987.

[19] B. P. Subedi, S. S. Pandey, A. Pandey et al., Forest Carbon Stock Measurement: Guidelines for Measuring Carbon Stocks in Community-Managed Forests, p. 69, ANSAB, Al Khobar, Saudi Arabia, 2010.
[20] L. C. Hamilton, Modern Data Analysis: A First Course in Applied Statistics, Brooks/Cole, Pacific Grove, CA, USA, 1990.

[21] J. Archer, Crop Nutrition and Fertiliser Use, Farming Press, Chicago, IL, USA, 1985.

[22] J. S. Greenwood and G. Batten, Mechanisms and Regulation of Mineral Nutrient Storage during Seed Development, Seed Development and Germination, pp. 215-235, Marcel Dekker, New York, NY, USA, 1995.

[23] A. E. Hartemink, "Biomass and nutrient accumulation of Piper aduncum and Imperata cylindrica fallows in the humid lowlands of Papua New Guinea," Forest Ecology and Management, vol. 144, no. 1-3, pp. 19-32, 2001.

[24] E. L. Dossa, E. C. M. Fernandes, W. S. Reid, and K. Ezui, "Above- and belowground biomass, nutrient and carbon stocks contrasting an open-grown and a shaded coffee plantation," Agroforestry Systems, vol. 72, no. 2, pp. 103-115, 2008.

[25] C. Adu-Anning, L. Angalaare, and L. Nwoboshi, "Growth, energy yield and nutrient uptake of some fuelwood species in the Sudan Savanna of Ghana," Journal of Tree Science, vol. 14, 1993.

[26] L. Nwoboshi, "Biomass and nutrient uptake and distribution in gmelina pulpwood plantation age-series in Nigeria," Journal of Tropical Forest Resources, vol. 1, no. 1, pp. 53-62, 1985.

[27] E. Owusu-Sekyere, J. Cobbina, and T. Wakatsuki, "Nutrient cycling in primary, secondary forests and cocoa plantation in the Ashanti Region, Ghana, West," African Journal of Applied Ecology, vol. 9, no. 1, pp. 10-18, 2009.

[28] M. Rai, Principles of Soil Science, Macmillan, New York, NY, USA, 2002.

[29] H. D. Foth and B. G. Ellis, Soil Fertility, CRC Press, Boca Raton, FL, USA, 1997.

[30] Y. Ahenkorah, B. Halm, M. Appiah, and G. Akrofi, "Fertilizer use on cacao rehabilitation projects in Ghana," in Proceedings 8th International Cocoa Research Conference, pp. 165-170, Cocoa Producers' Alliance, Cartagena, Colombia, October 1981.

[31] K. Ofori-Frimpong, A. Asase, J. Mason, and L. Danku, "Shaded versus unshaded cocoa: implications on litter fall, decomposition, soil fertility and cocoa pod development," in Proceedings of the 2nd International Symposium on Multistrata Agroforestry Systems with Perennial Crops: Making Ecosystem Service Count for Farmers, Consumers and the Environment, Turrialba, Costa Rica, September, 2007, https:// http://web.catie.ac.cr/AFS/Symposium.

[32] E. Owusu-Bennoah, T. Awadzi, E. Boateng, L. Krogh, H. Breuning-Madsen, and O. Borggaard, "Soil properties of a toposequence in the moist semi-deciduous forest zone of Ghana," West African Journal of Applied Ecology, vol. 1, no. 1, pp. 1-10, 2008.

[33] V. Agoumé and A. Birang, "Impact of land-use systems on some physical and chemical soil properties of an oxisol in the humid forest zone of southern Cameroon," Tropicultura, vol. 27, no. 1, pp. 15-20, 2009.

[34] C. N. Egbuchua and B. O. Bosah, "Characterization of some forest soil under teak (Tectona grandis) plantation in humid forest region of Nigeria," International Journal of Science and Nature, vol. 2, no. 3, pp. 821-825, 2011.

[35] R. Uchida, "Essential nutrients for plant growth: nutrient functions and deficiency symptoms," Plant Nutrient Management in Hawaii's Soils, vol. 4, pp. 31-55, 2000.

[36] P. A. Sánchez, W. Couto, and S. W. Buol, “The fertility capability soil classification system: interpretation, applicability 
and modification," Geoderma, vol. 27, no. 4, pp. 283-309, 1982.

[37] R. Asiamah, Edited by A. Bationo, Ed., Edited by R. Tabo, Ed., Edited by B. Waswa, Ed., Edited by J. Okeyo, Ed., Edited by J. Kihara, Ed., Edited by M. Fosu, Ed., "Soil resources of Ghana," in Synthesis of Soil, Water and Nutrient Management Research in the Volta Basin, S. Kabore, Ed., p. 25, Ecomedia Ltd., Nairobi, Kenya, 2008.

[38] C. Nolte, T. Tiki-Manga, S. Badjel-Badjel, J. Gockowski, S. Hauser, and S. F. Weise, "Effects of calliandra planting pattern on biomass production and nutrient accumulation in planted fallows of southern Cameroon," Forest Ecology and Management, vol. 179, no. 1-3, pp. 535-545, 2003. 